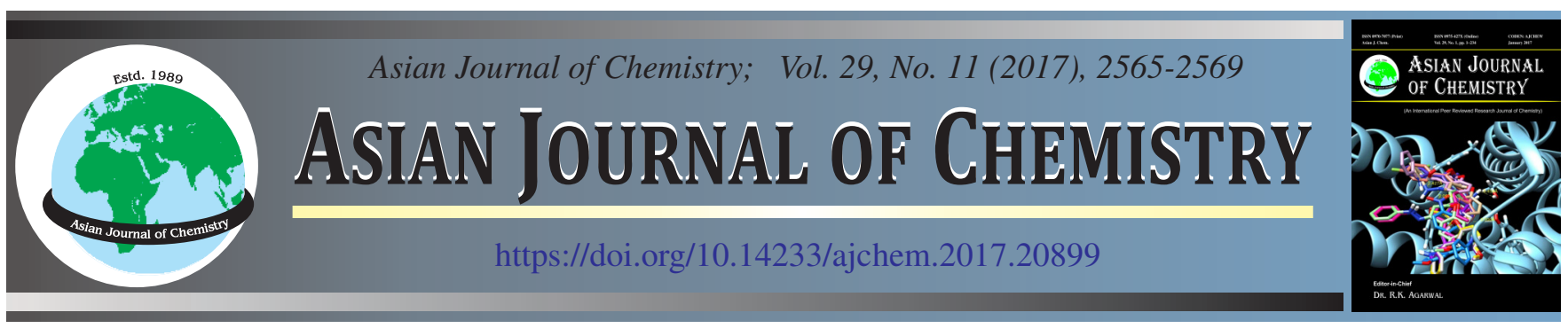

\title{
A Bioanalytical Method Development and Validation for Simultaneous Determination of Velpatasvir and Sofosbuvir in Spiked Human Plasma
}

\author{
R.S. Ch. Phani ${ }^{1, *}$, K.R.S. Prasad ${ }^{1}$ and Useni Reddy Mallu ${ }^{2}$
}

${ }^{1}$ Department of Chemistry, K.L. University, Vaddeswaram-522 502, India

${ }^{2}$ R.V. Labs, Guntur-522 007, India

*Corresponding author: E-mail: phani.r.s.ch@gmail.com

Received: 1 July 2017

Accepted: 28 August 2017;

Published online: 29 September 2017;

AJC-18592

A simple, precise, accurate and sensitive, isocratic RP-HPLC method has been developed and validated for the estimation of velpatasvir
and sofosbuvir in plasma. Method was developed with, Intersil ODS C18 column $(250 \mathrm{~mm} \times 4.6 \mathrm{~mm} \times 5 \mu)$, mobile phase mixture of
acetonitrile and water having $\mathrm{pH}$ of 6.5 in the ratio of $(80: 20 \mathrm{v} / \mathrm{v})$ at flow rate $1 \mathrm{~mL} / \mathrm{min}$. at UV detector wavelength of $240 \mathrm{~nm}$. Mobile
phase $\mathrm{pH}$ was adjusted with $1 \% o$-phthalaldehyde $(\mathrm{OPA})$. The retention times are $3.49 \mathrm{~min}$ for sofosbuvir and $6.15 \mathrm{~min}$ for velpatasvir,
Quantitative linearity was obeyed in the concentration range of 0.1 to $0.8 \mu \mathrm{g} / \mathrm{mL}$ for sofosbuvir and 0.025 to $0.2 \mu \mathrm{g} / \mathrm{mL} \mathrm{for} \mathrm{velpatasvir.}$
The limit of detections are $0.006 \mu \mathrm{g} / \mathrm{mL}$ for sofosbuvir, $0.0017 \mu \mathrm{g} / \mathrm{mL}$ for velpatasvir and limit of quantifications are $0.0125 \mu \mathrm{g} / \mathrm{mL}$ for
sofosbuvir, $0.003 \mu \mathrm{g} / \mathrm{mL}$ for velpatasvir for which indicates the sensitivity of the method. The average recovery of sofosbuvir is 100.75
and $99.25 \%$ for velpatasvir. The high percentage recovery indicates that the proposed method is highly accurate. Bench top, Auto
sampler, Freeze and Thaw stability test are performed.

Keywords: Velpatasvir, Sofosbuvir, HPLC Method, Bioanalytical method.

\section{INTRODUCTION}

Sofosbuvir (Fig. 1) is a prodrug of 2'-deoxy-2'-fluoro-2'C-methyl-uridine monophosphate that is phosphorylated intra cellularly to the active triphosphate form, used for the treatment of chronic hepatitis $\mathrm{C}$. The nucleoside triphosphate is a nonobligate chain-terminating analogue of UTP that competes for incorporation at the HCV NS5B polymerase active site. Viral RNA synthesis is inhibited secondary to incorporation of the phosphorylated metabolite into nascent viral RNA by the HCV RNA-dependent RNA polymerase [1]. Velpatasvir (Fig. 1) is both an inhibitor and a substrate of the transporter proteins P-glycoprotein (Pgp), ABCG2, OATP1B1 and OATP1B3. It is partly degraded by the liver enzymes CYP2B6, CYP2C8 and CYP3A4 [2].

Literature survey revealed that very few analytical methods were available for analysis of sofosbuvir and velpatasvir. Most of the methods were reported for analysis of sofosbuvir. Raj Kumar and Subrahmanyam [3] developed a HPLC method for the simultaneous quantification of sofosbuvir in pharmaceutical dosage form. In this reported method, mobile phase was a mixture of acetonitrile:water (75:25\% v/v). Method was developed at a wavelength of $253 \mathrm{~nm}$ with C18 column. The linearity range was $18.2-91 \mathrm{mg} / \mathrm{mL}$ for sofosbuvir. Zaman et al. [4] reported a simultaneous method for the determination of sofosbuvir. In this method, the mobile phase consists of $\mathrm{CH}_{3} \mathrm{COONH}_{4}$ and acetonitrile $(35: 65 \% \mathrm{v} / \mathrm{v})$. Method was developed with C8 column, at $245 \mathrm{~nm}$. Vikas et al. [5] reported a method for the determination of sofosbuvir in pure form. In this method mobile was phosphate buffer and methanol in $50: 50 \% \mathrm{v} / \mathrm{v}$, flow rate is $0.8 \mathrm{~mL} / \mathrm{min}$. Method developed at $262 \mathrm{~nm}$. The linearity range was reported between 5-30 $\mu \mathrm{g}$ / $\mathrm{mL}$. Hassouna et al. [6] reported a method for simultaneous determination of sofosbuvir and ledipasvir by RP-HPLC method in tablet dosage forms. This method was developed with $0.02 \mathrm{M} \mathrm{KH}_{2} \mathrm{PO}_{4}$ and $5.7 \mathrm{mM}$ hexane sulfonate, acetonitrile as mobile phase at $1.5 \mathrm{~mL} / \mathrm{min}$ flow rate. The UV detector wavelength is $254 \mathrm{~nm}$. Vejendla et al. [7] submitted a method for the estimation of sofosbuvir in bulk and tablet dosage form. The method was developed with methanol and trifluoroacetic acid as mobile phase and $150 \mathrm{~mm}$ ODS column as stationary phase. The linearity was $100-600 \mu \mathrm{g} / \mathrm{mL}$. Chakravarthy et al. [8] reported an ultraviolet-visible spectroscopic method for estimation of daclatasvir and sofosbuvir. In this method, 99.7$100.6 \%$ recovery was reported for sofosbuvir. Bioanalytical methods are simultaneous estimation in plasma methods are not reported. The present study is concerned with the development and validation of sofosbuvir and velpatasvir in spiked human plasma by high performance liquid chromatography. 


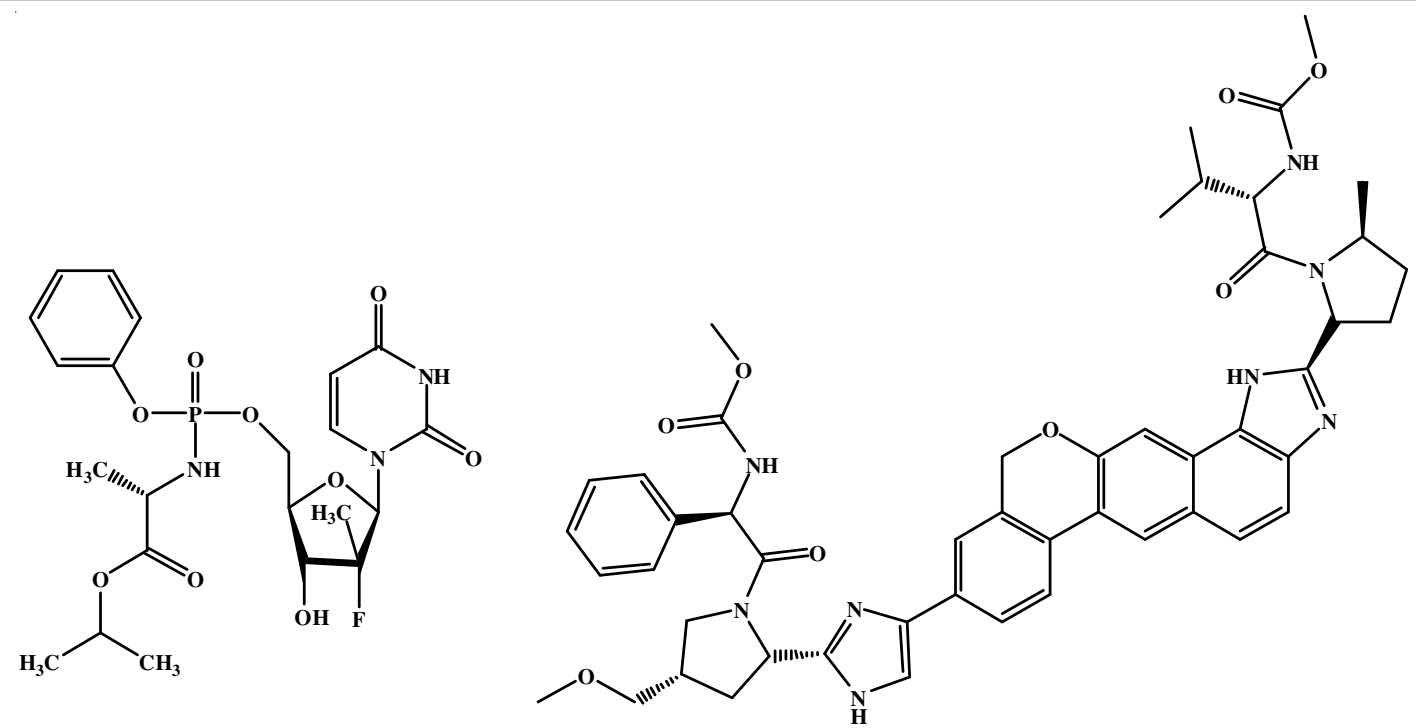

Fig. 1. Structure of sofosbuvir and velpatasvir

\section{EXPERIMENTAL}

The method was developed and validated with Peak LC P7000HPLC (Isocratic) system rheodyne injector with $20 \mu \mathrm{L}$ and UV/visible detector UV7000 and PEAK chromatographic version 1.06. The sofosbuvir and velpatasvir were scanned with UV-visible spectrophotometer (Tech comp-UV 2301, Japan) with Hitachi software. Sofosbuvir and velpatasvir were obtained from Alcon Laboratories, Mumbai. HPLC grade solvents water, acetonitrile, methanol and ortho phosphoric acid (OPA) were procured from Merck, Mumbai. Method was developed with Intersil ODS C18 column $(250 \mathrm{~mm} \times 4.6 \mathrm{~mm}$ $\times 5 \mu)$ at $240 \mathrm{~nm}$. The overlay scanning spectra showed in Fig. 2 .

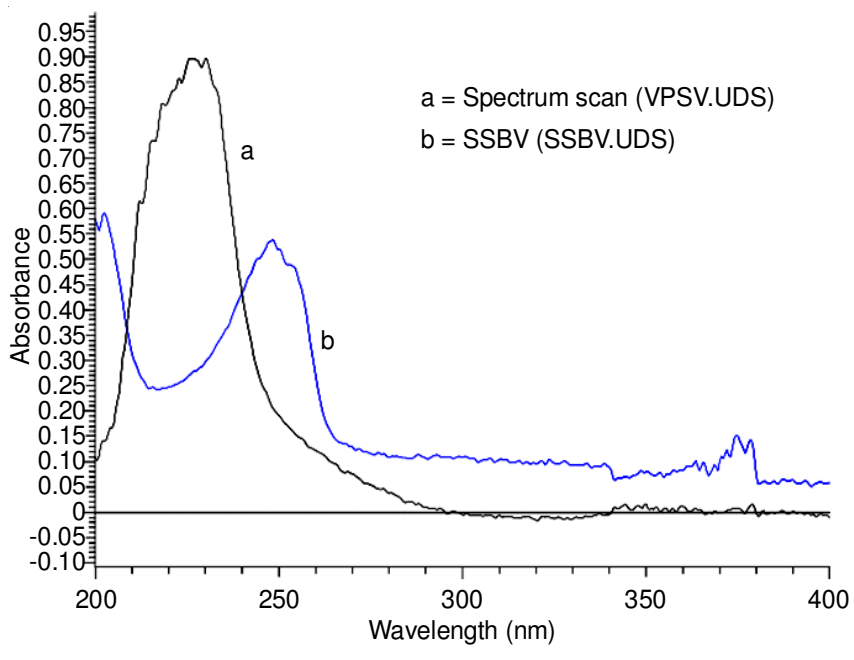

Fig. 2. Overlay of sofosbuvir and velpatasvir

\section{Chromatographic conditions}

Optimization of chromatographic conditions: Drugs solubilities were examined and mobile phase was fixed after trail with different ratios of mobile phase combinations. The detection wavelength was optimized in the double beam spectrophotometer, by scanning sample in the range of 200-400 nm. From the overlaid spectrum of sofosbuvir and velpatasvir, 240 $\mathrm{nm}$ was selected for the simultaneous quantification of sofosbuvir and velpatasvir in HPLC method. The finalized HPLC conditions are showed in Table- 1 .

\begin{tabular}{ll} 
& TABLE-1 \\
& $\begin{array}{l}\text { CHROMATOGRAPHIC CONDITIONS } \\
\text { OF DEVELOPED METHOD }\end{array}$ \\
\hline Parameter & Condition \\
\hline Mobile phase & $20 \%$ Water and $80 \%$ acetonitrile v/v \\
$\mathrm{pH}$ & $6.5($ Adjusted with OPA) \\
Column & Intersil ODS $\mathrm{C}_{18}$ column $(250 \mathrm{~mm} \times 4.6$ \\
& $\mathrm{mm} \times 5 \mu)$ \\
Flow rate & $1.0 \mathrm{~mL} / \mathrm{min}$ \\
UV detector wavelength & $240 \mathrm{~nm}$ \\
Run time & $10 \mathrm{~min}$ \\
Sample volume & $20 \mu \mathrm{L}$ \\
\hline
\end{tabular}

Standard stock solution preparation [9]: The extraction of the plasma samples involved liquid-liquid extraction process. The fixed dosages $(10 \mathrm{mg})$ are spiked in to $10 \mathrm{~mL}$ plasma and stored for $24 \mathrm{~h}$. For processing, the stored spiked samples were withdrawn from the freezer and allowed to thaw at room temperature. An aliquot of $500 \mu \mathrm{L}$ was transferred to prelabeled $10.0 \mathrm{~mL}$ polypropylene centrifuge tubes. Extraction solvent, $5.0 \mathrm{~mL}$ of ethyl acetate, was then added to extract the drug. The samples were then kept on a vibramax unit and vortexed for $15 \mathrm{~min}$. Samples were then centrifuged at $5000 \mathrm{rpm}$ for $5 \mathrm{~min}$ in a refrigerated centrifuge $\left(4^{\circ} \mathrm{C}\right)$. Supernatant solution, $1 \mathrm{~mL}$ was then transferred into pre-labeled polypropylene tubes and was allowed to evaporate to dryness under nitrogen at $40{ }^{\circ} \mathrm{C}$. The dried residue was then dissolved in $200 \mu \mathrm{L}$ of mobile phase and transferred into shell vials containing vial inserts for analysis. Samples, $20 \mu \mathrm{L}$ by volume, were then injected into the column and analyzed by HPLC on the same day to avoid any degradation. The column temperature oven was maintained at ambient temperature. The blank chromatogram and standard chromatograms are showed in Figs. 3 and 4.

\section{Validation}

Linearity test: The linearity of calibration curves (peak area $v s$. concentration) in pure solution was checked over the concentration ranges of about $0.1-0.8 \mu \mathrm{g} / \mathrm{mL}$ and $0.025-0.2$ 


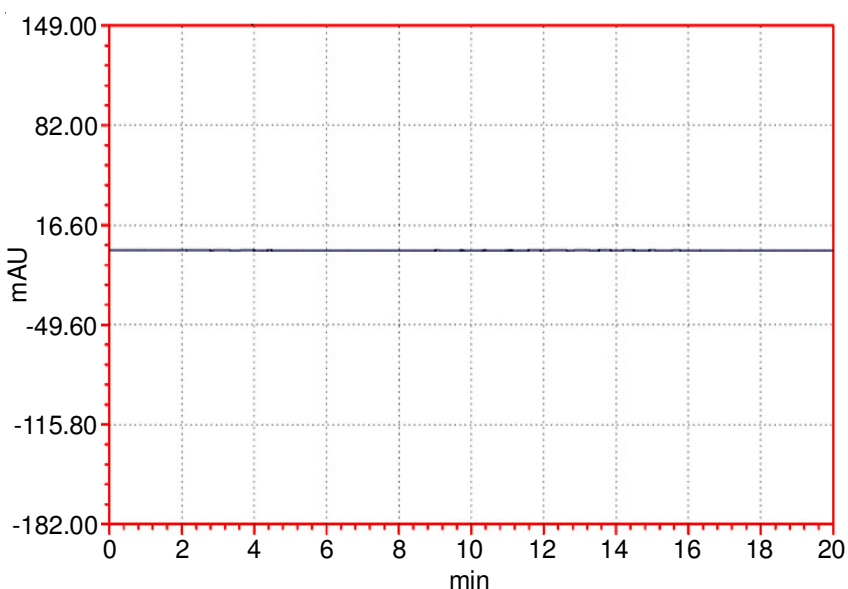

Fig. 3. Blank chromatogram

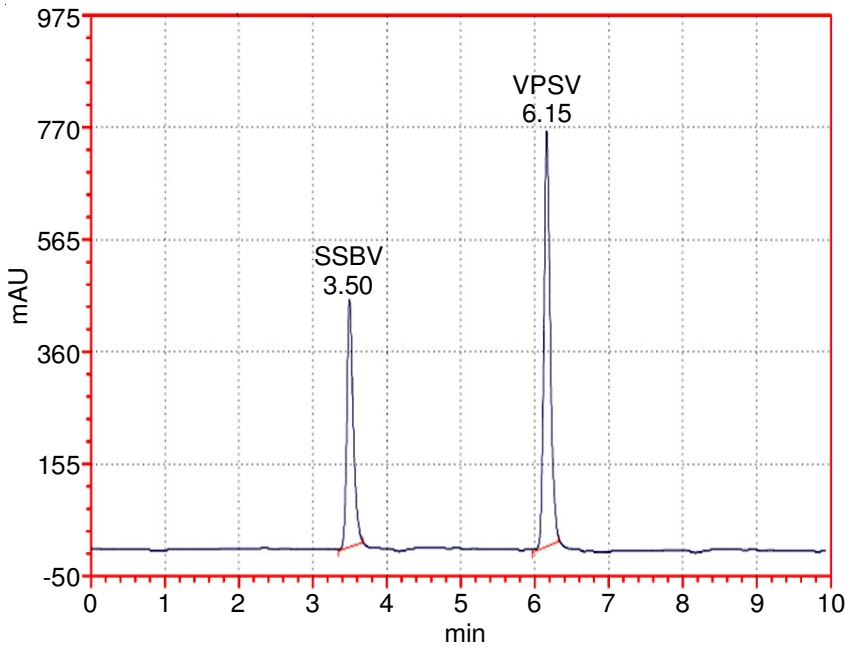

Fig. 4. Standard chromatogram of sofosbuvir and velpatasvir

$\mu \mathrm{g} / \mathrm{mL}$ for sofosbuvir and velpatasvir. The total runtime was $10 \mathrm{~min}$. The regression line relating standard concentrations of drug using regression analysis, the calibration curves were linear in the studied range and equations of the regression analysis were obtained (Table-2). The linearity graphs of sofosbuvir and velpatasvir are showed in Figs. 5 and 6, respectively.

TABLE-2

LINEARITY RESULTS OF DEVELOPED METHOD

\begin{tabular}{ccc|cc}
\hline Conc. $(\%)$ & $\begin{array}{c}\text { Sofosbuvir } \\
\text { conc. }(\mu \mathrm{g} / \mathrm{mL})\end{array}$ & $\begin{array}{c}\text { Peak } \\
\text { area }\end{array}$ & $\begin{array}{c}\text { Velpatasvir } \\
\text { conc. }(\mu \mathrm{g} / \mathrm{mL})\end{array}$ & $\begin{array}{c}\text { Peak } \\
\text { area }\end{array}$ \\
\hline 25 & 0.1 & 174546 & 0.025 & 218928 \\
50 & 0.2 & 210703 & 0.05 & 313402 \\
100 & 0.4 & 270338 & 0.1 & 450194 \\
150 & 0.6 & 324035 & 0.15 & 606346 \\
200 & 0.8 & 393474 & 0.2 & 748597 \\
\hline $\mathrm{r}^{2}$ & 0.9990 & \multicolumn{2}{c}{0.9993} & \\
Slope & 305580.1 & \multicolumn{2}{c}{2995120} & 153005.8 \\
Intercept & 146275.5 & \multicolumn{2}{c}{} \\
\hline
\end{tabular}

Precision: Intra-day precision was investigated by replicate applications and measurements of peak area of sofosbuvir and velpatasvir for six times on the same day under similar conditions. Inter-day precision was obtained from \% RSD values obtained by repeating the assay six times on two different days. The \% RSD was calculated (Tables 3 and 4), which was within the acceptable limit i.e. less than 2.0.
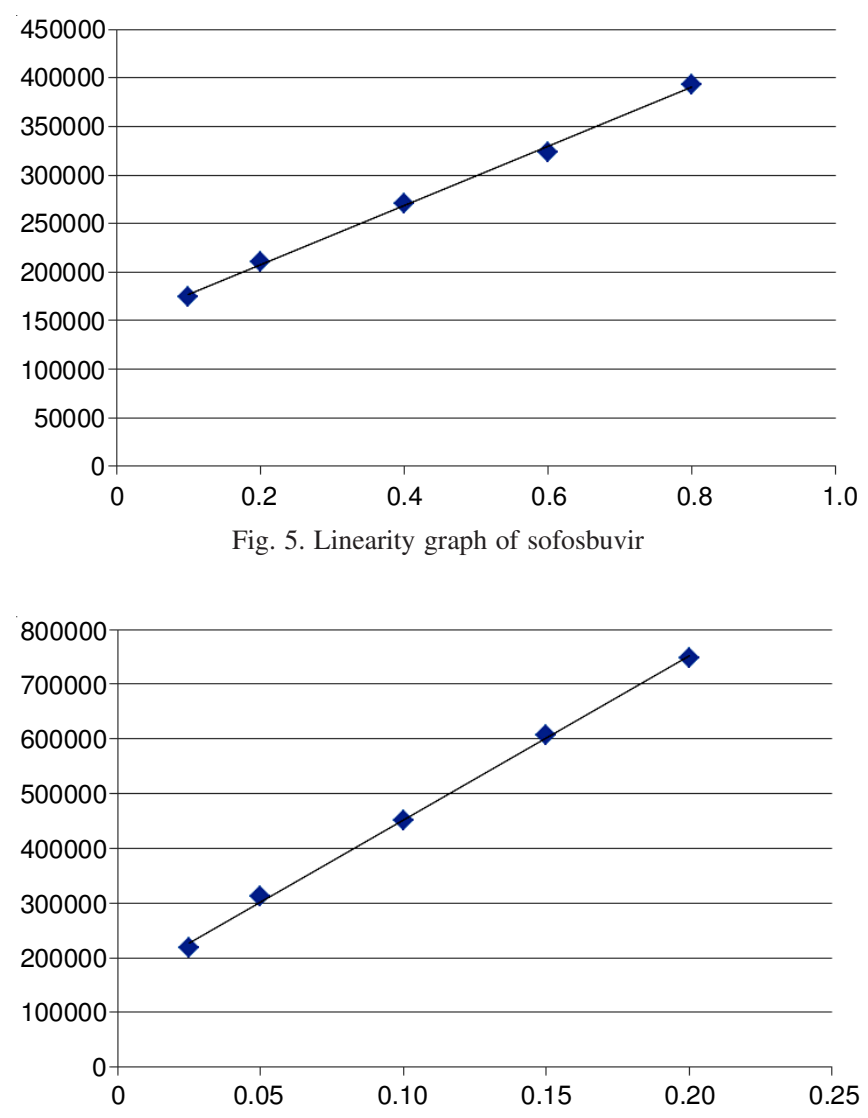

Fig. 6. Linearity graph of velpatasvir

TABLE-3

INTRA-DAY RESULTS OF DEVELOPED METHOD

\begin{tabular}{ccc|cc}
\hline S. No. & $\begin{array}{c}\text { Sofosbuvir } \\
\text { conc. }(\mu \mathrm{g} / \mathrm{mL})\end{array}$ & $\begin{array}{c}\text { Peak } \\
\text { area }\end{array}$ & $\begin{array}{c}\text { Velpatasvir } \\
\text { conc. }(\mu \mathrm{g} / \mathrm{mL})\end{array}$ & $\begin{array}{c}\text { Peak } \\
\text { area }\end{array}$ \\
\hline Injection-1 & 0.40 & 268737 & 0.10 & 449503 \\
Injection-2 & 0.40 & 279772 & 0.10 & 453586 \\
Injection-3 & 0.40 & 276166 & 0.10 & 451094 \\
Injection-4 & 0.40 & 269261 & 0.10 & 455082 \\
Injection-5 & 0.40 & 277882 & 0.10 & 450686 \\
Injection-6 & 0.40 & 278001 & 0.10 & 449168 \\
\hline RSD (\%) & \multicolumn{2}{|c|}{0.51} \\
\hline
\end{tabular}

TABLE-4

INTER-DAY RESULTS OF DEVELOPED METHOD

\begin{tabular}{ccc|cc} 
S. No. & $\begin{array}{c}\text { Sofosbuvir } \\
\text { conc. }(\mu \mathrm{g} / \mathrm{mL})\end{array}$ & $\begin{array}{c}\text { Peak } \\
\text { area }\end{array}$ & $\begin{array}{c}\text { Velpatasvir } \\
\text { conc. }(\mu \mathrm{g} / \mathrm{mL})\end{array}$ & $\begin{array}{c}\text { Peak } \\
\text { area }\end{array}$ \\
\hline Injection-1 & 0.4 & 269525 & 0.1 & 459062 \\
Injection-2 & 0.4 & 271142 & 0.1 & 456229 \\
Injection-3 & 0.4 & 274015 & 0.1 & 445129 \\
Injection-4 & 0.4 & 274157 & 0.1 & 443597 \\
Injection-5 & 0.4 & 264785 & 0.1 & 458365 \\
Injection-6 & 0.4 & 274505 & 0.1 & 445404 \\
\hline RSD (\%) & \multicolumn{2}{c|}{1.39} & \multicolumn{2}{|c}{1.61} \\
\hline
\end{tabular}

Recovery: Accuracy of the method was determined by recovery studies. To the formulation (pre analyzed sample), the reference standards of the drugs were added at the level of $50 \%, 100 \%, 150 \%$. The recovery studies were carried out three times and the percentage recovery and percentage relative standard deviation of the recovery were calculated for both drugs and shown in the Table-5. 
TABLE-5

RECOVERY RESULTS OF DEVELOPED METHOD

\begin{tabular}{|c|c|c|c|c|c|c|}
\hline $\begin{array}{c}\text { Concentration } \\
\text { level }(\%)\end{array}$ & Sofosbuvir & True area & Recovery (\%) & Velpatasvir & True area & Recovery (\%) \\
\hline 50 & 216099 & 210703 & 102.5 & 308121 & 313402 & 98.31 \\
\hline 100 & 267879 & 270338 & 99.09 & 451643 & 450194 & 100.32 \\
\hline 150 & 326223 & 324035 & 100.67 & 601180 & 606346 & 99.14 \\
\hline Average recovery & & 100.75 & & & 99.25 & \\
\hline
\end{tabular}

Sensitivity: The sensitivity was determined by signal to noise $(\mathrm{S} / \mathrm{N})$ ratio. The resolution solution was serially diluted and injections were made to obtain chromatogram. Similarly, blank plasma samples were also processed and injected in to chroma-tograph. The results were showed in Table- 6 .

\begin{tabular}{ccc}
\multicolumn{3}{c}{ TABLE-6 } \\
LOQ AND LOD RESULTS OF DEVELOPED METHOD \\
\hline Test & Sofosbuvir $(\mu \mathrm{g} / \mathrm{mL})$ & Velpatasvir $(\mu \mathrm{g} / \mathrm{mL})$ \\
\hline LOQ & 0.0125 & 0.0030 \\
LOD & 0.0060 & 0.0017 \\
\hline
\end{tabular}

Stability: The stability experiments were aimed at testing all possible conditions that the samples might experience after collecting and prior the analysis. Short term bench-top stability was evaluated after $24 \mathrm{~h}$ at room temperature. Auto sampler stability was evaluated on QCs extracts maintained in the auto sampler at $10{ }^{\circ} \mathrm{C}$ for $24 \mathrm{~h}$, by comparing their concentrations with fresh extracts. Freeze and thaw stability have been evaluated after three cycles at $-20^{\circ}$ to room temperature, by comparison with freshly prepared. Stability of sofosbuvir and velpatasvir solutions was observed at room and temperature and in refrigerated conditions for period of $48 \mathrm{~h}$. Acceptable stability has been considered as percent difference in concentration lower than $5 \%$. The stability study reports were showed in Table-7. The blank chromatogram and the stability tests chromatograms are showed in Figs. 7-10.

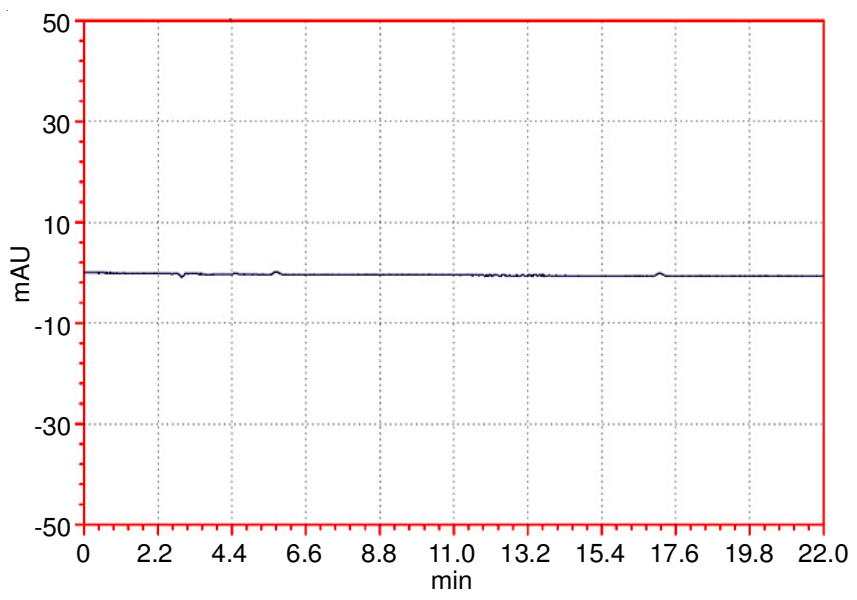

Fig. 7. Blank chromatogram of stability test

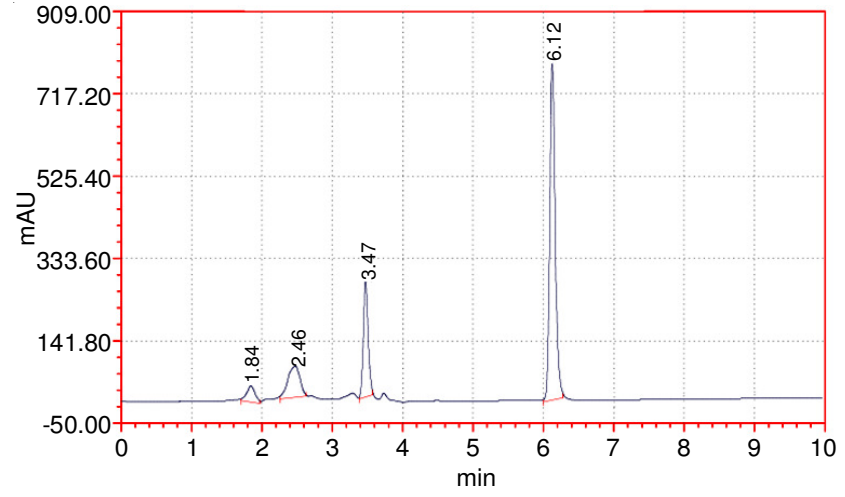

Fig. 8. Bench-top stability test chromatogram of sofosbuvir and velpatasvir

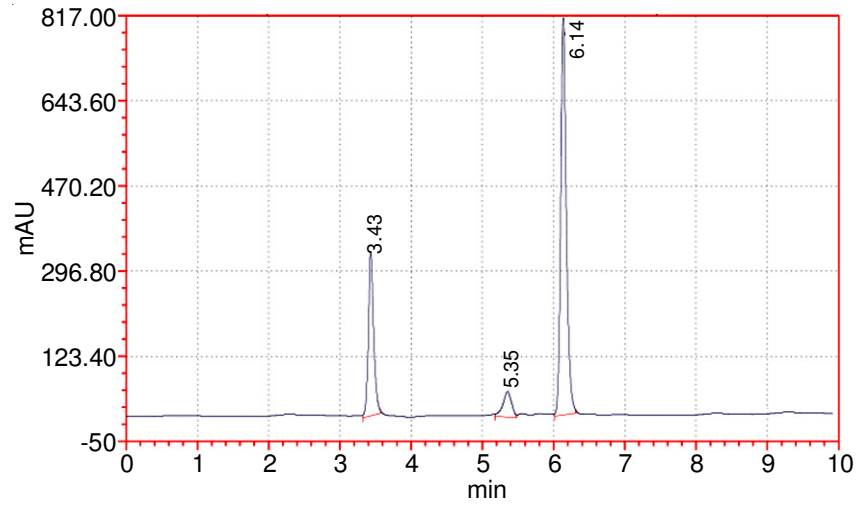

Fig. 9. Auto sampler stability test chromatogram of sofosbuvir and velpatasvir

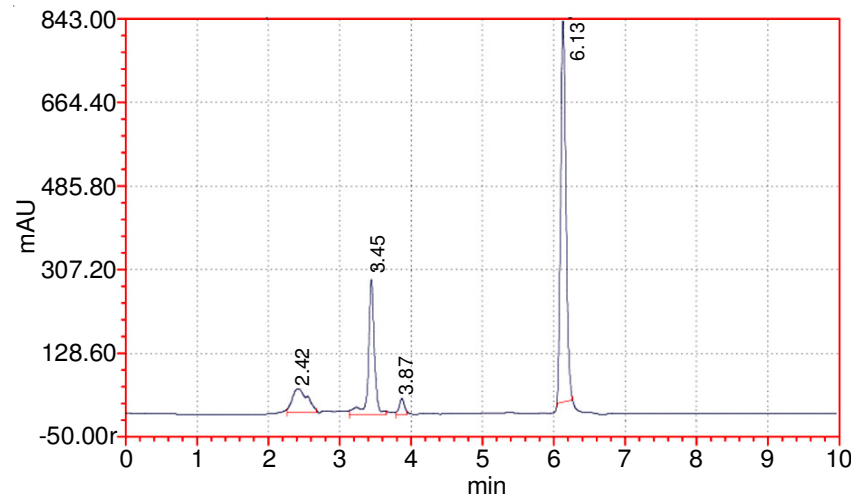

Fig. 10. Freeze and Thaw stability test chromatogram of sofosbuvir and velpatasvir

TABLE-7

STABILITY RESULTS OF DEVELOPED METHOD

\begin{tabular}{cccccc}
\hline S. No. & Stability test & Sofosbuvir & Percentage of change & Velpatasvir & Percentage of change \\
\hline 1 & Blank & 00 & 00 & 00 & 00 \\
2 & Freshly prepared & 270338 & 00 & 450194 & 00 \\
3 & Bench top & 128534 & 52.45 & 419692 & 6.77 \\
4 & Auto sampler & 171722 & 36.4 & 440446 & 2.16 \\
5 & Freeze \& Thaw & 167866 & 37.90 & 415005 & 7.81 \\
\hline
\end{tabular}




\section{RESULTS AND DISCUSSION}

New RP- HPLC method had been developed for simultaneous estimation of sofosbuvir and velpatasvir in plasma. It was shown that the method was precise, accurate, reproducible, linear, selective and specific providing the reliability of the method. The method was validated over the concentration range of $0.1-0.8 \mu \mathrm{g} / \mathrm{mL}$ for sofosbuvir and $0.025-0.2 \mu \mathrm{g} / \mathrm{mL}$ for velpatasvir. The mean percent recovery of sofosbuvir is $100.75 \%$ and for velpatasvir is $99.25 \%$. The intra- and interday precision were conducted at standard concentration, the percen-tage of RSD is below $2 \%$. Stability of compounds was estab-lished in a series of stability studies. The LOQ concentration of sofosbuvir is $0.0125 \mu \mathrm{g} / \mathrm{mL}$ and velpatasvir is $0.003 \mu \mathrm{g} / \mathrm{mL}$. The LOD concentration of sofosbuvir is 0.006 $\mu \mathrm{g} / \mathrm{mL}$ and velpatasvir is $0.0017 \mu \mathrm{g} / \mathrm{mL}$. Bench-top stability, auto sampler stability and freeze $\&$ thaw stability are conducted with the sample solution. The change in stability test of sofosbuvir is 52.45, 36.4 and $37.90 \%$ in Bench-top stability, Auto sampler stability and freeze and thaw stability respectively. The change in stability test of velpatasvir is $6.77,2.16$ and $7.81 \%$ in benchtop stability, auto sampler stability and freeze and thaw stability, respectively.

\section{Conclusion}

The bioanalytical method developed is simple and good accuracy and reproducible. It can be used for the estimation of sofosbuvir and velpatasvir in plasma. The method was validated for linearity, accuracy, precision, LOD, LOQ and recovery. The method was fully validated and showing satisfactory data for all the method validation parameters tested. The recoveries achieved are good by the method. The developed method could be applied in bioequivalence, pharmacokinetic, regular analysis and toxicokinetic studies.

\section{REFERENCES}

1. L.S. Goodman and A.G. Gilman, eds.: J.G. Hardman and L.E. Limbard, The Pharmacological Basis of Therapeutics, McGraw Hill, edn 9 (1996).

2. J.J. Feld, I.M. Jacobson, C. Hézode, T. Asselah, P.J. Ruane, N. Gruener, A. Abergel, A. Mangia, C.-L. Lai, H.L.Y. Chan, F. Mazzotta, C. Moreno, E. Yoshida, S.D. Shafran, W.J. Towner, T.T. Tran, J. McNally, A. Osinusi, E. Svarovskaia, Y. Zhu, D.M. Brainard, J.G. McHutchison, K. Agarwal and S. Zeuzem, N. Engl. J. Med., 373, 2599 (2015); https://doi.org/10.1056/NEJMoa1512610.

3. B. Raj Kumar and K.V. Subrahmanyam, Indo-Am. J. Pharm. Res., 6, 450 (2016).

4. B. Zaman, F. Siddique and W. Hassan, Chromatographia, 79, 1605 (2016); https://doi.org/10.1007/s10337-016-3179-9.

5. M. Vikas, T. Satyanarayana, D. Vinod Kumar, E. Mounika, M. Sri Latha, R. Anusha and Y. Sathish, World J. Pharm. Pharm. Sci., 5, 775 (2016).

6. M. El-Kassem M. Hassouna, M.M. Abdelrahman and M.A. Mohamed, J. Forensic Sci. Crim. Invest., 1, 555562 (2017); https://doi.org/10.19080/JFSCI.2017.01.555562.

7. R. Vejendla, C.V.S. Subramanyam and G. Veerabhadram, Indo-Am. J. Pharm. Res., 5, 2098 (2015).

8. V.A. Chakravarthy, B.B.V. Sailaja and A.P. Kumar, Asian J. Pharm. Clin. Res., 9, 61 (2016); https://doi.org/10.22159/ajpcr.2016.v9s2.13687.

9. B. Prasanthi, J.V. Ratna and R.S.C. Phani, J. Anal. Chem., 70, 1015 (2015); https://doi.org/10.1134/S1061934815080146. 